\title{
Application and validation of a warning system for grapevine downy mildew control using fungicides
}

\author{
Erlei Melo Reis ${ }^{1}$, Olavo Roberto Sônego ${ }^{2}$ \& Cristiano de Sales Mendes ${ }^{3}$
}

${ }^{1}$ Faculdade de Agronomia e Medicina Veterinária, Universidade de Passo Fundo, 99001970 Passo Fundo, RS, E-mail: erleireis@tpo.com.br; ${ }^{2}$ Embrapa Uva e Vinho, Cx. Postal 130, CEP 95700 000, Bento Gonçalves, RS; ${ }^{3}$ COODETEC - Cooperativa Central de Pesquisa Agrícola, Cascavel, PR

Autor para correspondência: Erlei Melo Reis (erleireis@tpo.com.br)

Data de chegada: 20/01/2010. Aceito para publicação em: 20/01/2013.

\section{ABSTRACT}

Reis, E.M.; Sônego, O. R.; Mendes, C. S. Application and validation of a warning system for grapevine downy mildew control using fungicides. Summa Phytopathologica, v.39, n.1, p.10-15, 2013.

\begin{abstract}
Most warning systems for plant disease control are based on weather models dependent on the relationships between leaf wetness duration and mean air temperature in this period considering the target disease intensity. For the development of a warning system to control grapevine downy mildew, the equation generated by Lalancette et al. (7) was used. This equation was employed to elaborate a critical period table and program a computerized device, which records, though electronic sensors, leaf wetness duration, mean temperature in this period and automatically calculates the daily value of probability of infection occurrence. The system was validated at Embrapa Uva e
\end{abstract}

Vinho, in Bento Gonçalves - RS, during the growing seasons 2000/ $01,2002 / 03$ and $2003 / 2004$, using the grape cultivar Isabel. The conventional system used by local growers was compared with the new warning system by using different cumulative daily disease severity values (CDDSV) as the criterion to schedule fungicide application and reapplication. In experiments conducted in 2003/04, CDDSV of $12-$ 14 showed promising to schedule the first spraying and the interval between fungicide applications, reducing by $37.5 \%$ the number of applications and maintaining the same control efficiency in leaves and bunches, similarly to the conventional system.

Additional keywords: Plasmopara viticola, Vitis vinifera, forecaster system, chemical control.

\section{RESUMO}

Reis, E.M.; Sônego, O. R.; Mendes, C. S. Aplicação e validação de um sistema de aviso para o controle do míldio da videira, com fungicidas. Summa Phytopathologica, v.39, n.1, p.10-15, 2013.

A maioria dos sistemas de aviso para o controle de doenças de plantas utilizam como fundamento o modelo climático baseado nas interações entre a duração do molhamento foliar e a temperatura média nesse período sobre a intensidade da doença alvo. No desenvolvimento de um modelo de aviso para o controle do míldio da videira foi usado uma equação gerada por Lalancette et al., (7). Com esta equação foi elaborada uma tabela de períodos críticos e programado um aparelho computadorizado, o qual registra, através de sensores eletrônicos, a duração do molhamento foliar, a temperatura média nesse período e automaticamente calcula o valor diário de probabilidade de ocorrência da infecção.
O sistema foi validado na Embrapa Uva e Vinho, em Bento Gonçalves - RS, conduzido nas safras agrícolas de 2000/01, 2002/03 e 2003/ 2004 utilizando-se o cultivar Isabel. O sistema convencional utilizado pelos produtores foi comparado com o modelo de aviso utilizando como critério indicador do momento para a aplicação e reaplicação de fungicidas, diferentes somas dos valores diários de severidade (SVDS). O SVDS de 12 - 14, experimentos conduzidos em 2003/04 mostrou-se promissor para indicar a primeira e o intervalo das aplicações de fungicidas, tendo reduzido em $37,5 \%$ o número de aplicações e mantendo eficácia de controle da doença em folhas e cachos, semelhante ao sistema convencional.

Palavras-chave adicionais: Plasmopara viticola, Vitis vinifera, sistema de previsão, controle químico.

Grape (Vitis vinifera L.) cultivation in Brazil consists of around 57,000 hectares, with a mean yield of $15 \mathrm{t} / \mathrm{ha}(10)$. Fungal diseases are the main factors contributing to yield reduction. Downy mildew caused by the Oomycete Plasmopara viticola (Berk. \& Curt.), a Stramenopile, is considered the most important disease affecting grape in Brazil on account of frequent severe epidemics and destruction (6).

The main method for controlling downy mildew is fungicide application. At the present in Brazil, useful technical information for the critical timing of fungicide treatments to control the disease is not available and a scientific basis for timing fungicides is lacking. In general, from 8 to 10 sprayings are used per season for downy mildew control. The cost of chemical control is approximately $36 \%$ of the total cost of grape production (4). At present, fungicide applications are timed according to a pre-fixed calendar, not considering the pathogen biology, the plant phenologic stages or the suitability of micro-climate conditions for mildew epidemics. In several other countries, disease risk information is available to growers. This piece of information is often derived from disease simulation models that predict the risk of 
disease based on micro-climate data from weather stations in vineyards, regional climate conditions, pathogen biology and ecology, and grape phenology $(13,14)$.

Warning systems based on micro-climate models can be developed by using published data, containing information such as the relationships of vineyard weather factors related to the host infection by the pathogen (11). Warning systems are often based on tables that describe the interaction between leaf wetness duration, mean air temperature during the wet period and their relationship to predict the disease progress. Examples of such models for various pathogens include those developed for diseases affecting potato and tomato by Hyre (5), potato by Wallin (17), tomato by Madden et al. (9), apple scab by Ellis et al. (3), and carrot by Abraham et al. (1).

The aims of the present study were to develop and validate a warning system to rationalize the control of grape downy mildew using fungicides. A validated model has the potential to increase the chemical control efficiency, decrease the required number of fungicide sprayings, lower the cost of crop production and reduce the negative impact of chemicals on the environment.

\section{MATERIALAND METHODS}

\section{The model development}

The following equation of Lalancette et al. (7) was evaluated as a basis of a warning system to time fungicide sprayings against downy mildew: $\mathrm{S}=\left(-0.071+0.018 \mathrm{~T}-0.0005 \mathrm{~T}^{2}+0.01\right)(1+(\exp (-(0.24 \mathrm{wp}))+$ $(0.07 \mathrm{wpT}))-\left(0.0021 *\left(\mathrm{wp}^{*} \mathrm{~T}^{2}\right)\right) * 1 /(-1.2) * 11.2$, where $\mathrm{S}=$ downy mildew leaf severity, $\mathrm{T}=$ mean air temperature during the leaf wetness period, and $\mathrm{wp}=$ hours of continuous leaf wetness. Four classes of daily disease severity value (DDSV), designated as $0,1,2$, and 3 , were used to correspond respectively to zero, light, moderate and severe infection risk, as proposed by Sutton (16). Five classes of temperature range were used and indicated in Table 1. This equation was employed in combination with Excel 6.0 electronic sheet (Micorsoft 2000, Microsoft Corporation) to elaborate Table 1. Leaf wetness values were calculated for each DDSV based on the data for the disease severity in each temperature range. The effect of temperature was estimated for increments of $1.0^{\circ} \mathrm{C}$ and the variation of wetness, for increments of $1.0 \mathrm{~h}$. Estimated values of leaf wetness duration are shown in Table 1, which illustrates the interactions among four temperature ranges and 19 leaf wetness duration periods. This table was uploaded in an automatic weather station (AWS) equipped with a Colpam 40 (www.elomed.com.br) data logger which calculated leaf wetness duration to indicate the current DDSV. These scores were used to validate the model in field experiments.

\section{Model validation experiments}

Validation experiments were conducted at Embrapa Uva e Vinho in Bento Gonçalves, RS, in $3.0 \times 2.0 \mathrm{~m}$ vine spacing using the grape cultivar Isabel (Vitis labrusca L.), moderately susceptible to downy mildew.

\section{Experiment 1: Season 2000/01}

In the first step, the following treatment programs were tested: 1) Control without fungicide application; 2) Fungicide applied according to the growers' conventional method of spraying at $7-10$ day interval (first application with shoots of $15 \mathrm{~cm}$ long); 3) Timed fungicide applications according to the cumulative daily disease severity values (CDDSV), recorded and calculated by the data logger, as triggered by a CDDSV of $8-12$; 4) As previously, but triggered by DDSVS of 13 - 16; 5) As previously, but triggered by a CDDSV of 17 - 20; and 6) As previously, but triggered by a CDDSV of $21-24$. Dimethomorph $\left(150\right.$ g. $\left.\mathrm{L}^{-1}\right)$ at $150 \mathrm{~g} .100 \mathrm{~L}^{-1}$ water was applied at a rate of 50 to 1000 L.ha ${ }^{-1}$ depending on the grape canopy growth. The system triggered the first and subsequent sprayings.

\section{Experiment 2: Season 2002/03}

In this season, the following treatments were compared: 1) Control without fungicide applications; 2) Sprayings timed according to the grower's conventional method using mancozeb $\left(3.0 \mathrm{~kg} \cdot \mathrm{ha}^{-1}\right)$ and cymoxanil + maneb (ready mix) (2.5 kg.ha $\left.{ }^{-1}\right)$ at every $7-8$ days; 3$)$ Spraying of mancozeb (3.0 kg /ha) triggered by a CDDVS of $12-14$ and 4) Spraying of fungicide cymoxanil + maneb $\left(2.5 \mathrm{~kg} \cdot \mathrm{ha}^{-1}\right)$ triggered by CDDVS of $12-14$. Applications were performed with an air blast sprayer delivering 600 to 800 L.ha $^{-1}$ according to the grape canopy development.

\section{Experiment 3. Season 2003/04}

In this season, the following treatments were tested: 1) Control without fungicide application; 2) Sprayings according to the grower's conventional method, applying cymoxanil + maneb $\left(2.5 \mathrm{~kg} \cdot \mathrm{ha}^{-1}\right)$ at every $7-8$ days; 3 ); Spraying of cymoxanil + maneb $\left(2.5 \mathrm{~kg} \cdot \mathrm{ha}^{-1}\right)$ triggered by CDDSV of $12-14$. Fungicides were applied by using the same equipment as in Experiment 2.

\section{Experimental design}

The tested vineyards were divided into plots comprising three rows each, three vines in a completely randomized block design and four replicates. The area under the disease progress curves (AUDPC) and Tukey's multiple range test for mean comparison were used (2).

Disease assessment - In the growing season2000/01, the severity of downy mildew was weekly assessed on the leaves of four shoots per vine for three vines/plot. These data were used to draw the disease progress curves and calculate the AUDPC.

In 2002/03 and 2003/04, both leaf incidence and severity were assessed for 100 leaves taken arbitrarily from each plot, and the disease severity was evaluated for bunches according to the scale $0-5$, where $0=$ absence of symptoms; $1=$ up to $5 \%$ of the bunch infected; $2=6$ $-10 \% ; 3=11-25 \% ; 4=26-50 \% ; 5=$ more than $50 \%$ of the bunch infected.

Environmental data - A Colpam - 40 (AWS) data logger with sensors to measure leaf wetness duration and mean air temperature was installed in a control plot at the beginning of flowering for each experiment. The sensors were placed among the foliage and protected from direct sunlight.

\section{RESULTS AND DISCUSSION}

\section{The model system}

Warning systems for grape downy mildew have been developed and reported in other countries $(8,13,14,15)$. However, the technical information in these reports did not contain sufficient details for their validation in the field in Rio Grande do Sul State.

The equation of Lalancette et al. (7) was used to develop our model because this was the only one available in the literature. Lalancette et al. (7), however, did not suggest the use of their data to 
develop a warning system. Madden et al. (9) described a system to forecast grape downy mildews based on their previous study.

Most predicting systems, based on models using micro-climate data, utilize a critical period definition to forecast events by $P$. viticola infection. A population of fungal spores do not synchronically germinate in response to free water and temperature, so that different infection proportions (rates) and, in consequence, different disease intensities occur due to environmental factors. Each individual spore in a pathogenic population has specific wetness duration and temperature requirements to successfully complete infection (16). On the other hand, different disease intensities can be obtained through different inoculum concentrations, different temperatures and/or different leaf wetness durations. Hence, the interactions between leaf wetness duration and mean temperature during this period are the fundamental key of the warning systems based on the micro-climate effect on the infection process. Thus, they are named micro-climate models to forecast the infection process in plants (16).

The micro-climate model is based on the requirement for infection to occur and the plant disease triangle to be completed. In other words, the following are required at the same time and site: the host plant (susceptible green tissues of grapevine), the pathogen ( $P$. viticola), and a favorable environment. Mendes et al. (12) reported that spores of $P$. viticola are disseminated by the air every week throughout the year in Bento Gonçalves County - RS. Thus, leaf infection may potentially begin soon after the buds burst provided that the microclimate conditions, mainly leaf wetness and temperature, are favorable. In the present investigation, the model described in Table 1 was employed to determine favorableness of these variables for infection and optimal times to apply fungicides against downy mildew in vineyards near Bento Gonçalves.

\section{Model validation experiments Experiment 1: Season 2000/01}

Table 1. Table of critical leaf wetness periods showing the relationship between mean air daily temperature $\left({ }^{\circ} \mathrm{C}\right)$ and leaf wetness duration to produce different daily disease severity values (DDSV) of grape downy mildew caused by Plasmopara viticola

\begin{tabular}{ccccc}
\hline Temperature & \multicolumn{5}{c}{ Daily disease severity values } \\
\cline { 2 - 5 }$\left({ }^{\circ} \mathrm{C}\right)$ & 0 & \multicolumn{5}{c}{1} & 2 & 3 \\
\cline { 2 - 5 } & $<5$ & $5-13$ & $14-17$ & - \\
\hline $5-9$ & $<2$ & $2-10$ & $11-15$ & $>15$ \\
$10-14$ & $<2$ & $2-6$ & $7-13$ & $>13$ \\
$15-19$ & $<4$ & $3-9$ & $10-14$ & $>14$ \\
$20-24$ & $<4$ & $4-12$ & $13-14$ & $>14$ \\
$25-30$ & & \multicolumn{5}{c}{ Wetting hours } \\
\hline
\end{tabular}

$\overline{\mathrm{DDSV}}=0$, no symptoms; $1=$ leaf severity range from 0.1 to $0.5 \% ; 2=0.6$ to $1.0 \%$; ad 3 $=>1.0 \%$.

In this season, downy mildew symptoms were first detected on October 19, when CDDSV was 32. At 65 days after bud burst, the estimated disease severity was $49 \%$ for the leaves in control plots but only 18 to $35 \%$ for the various fungicide treatments (Figure 1).

The best leaf mildew control treatment, with the lowest AUDPC, was the conventional system; however, it was not statistically different from treatments with CDDSV 8-12, 13-16 or 17-20. In the control treatment, the leaf disease severity reached the highest value, but this gave an AUDPC score similar to that of treatment with CDDVS 2124 (Figure 1). In the conventional treatment, seven sprays were used and in the treatments timed by the warning system, 4, 3 and 2 applications were done, respectively, for treatments with CDDVS of 8-12, 13-16 and 17-20 (Figure 1).

Based on the data analysis for this experiment, a CDDSV of 12 14 was proposed to experiments conducted in the subsequent seasons, which promoted similar control as the conventional treatments.

Considering the fungicides used in the 2000-2001 season (Cymoxanil + maneb 250g/100L), cost of R \$ 70.00/ha (Sônego, personal information, 2001), and comparing the number of sprays with the

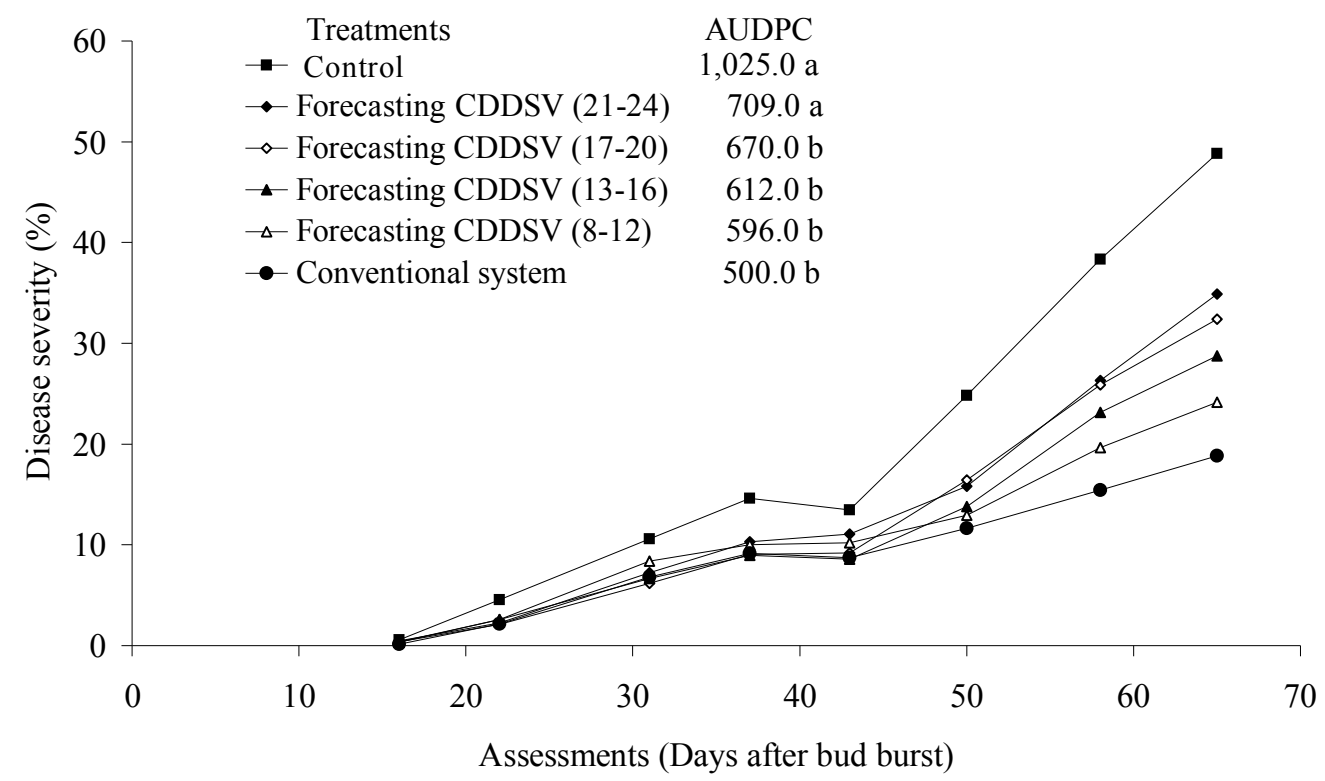

Figure 1. Disease progress curves and areas under the disease progress curve (AUDPC) for grape downy mildew considering leaf severity in the treatments. (CDDSV = cumulative daily disease severity value). Cultivar Isabel, 2000/01 season. Means followed by the same letter do not differ according to Tukey’s $(\mathrm{P}<0.05)$ multiple range test. 
traditional method, the warning system may lead to a reduction in costs of up to $\mathrm{R} \$ 490.00 / \mathrm{ha}$, also reducing the amount of chemical released in the environment, and showing the same downy mildew control efficiency.

\section{Experiment 2: Season 2002/03}

In this experiment, only four treatments were compared. In this case, the first symptoms were found on October 14, 2002 (29 days after bud burst). Severity of downy mildew in the control plots reached a value of $100 \%$ by 65 days after bud burst (Figure 2). At this time, disease severity in the various fungicide treatments was 23.6 to $26.3 \%$. AUDPC value of the control was statistically higher than the AUDPC values of the fungicide treatments, which did not significantly differ (Figure 2). These data indicated that the DDSVS value of $12-14$ was effective for timing the initial and subsequent fungicide applications, resulting in control similar to that of the conventional system.

As regards the effect of treatments on the disease incidence in the grape bunches, the most severe disease was found in control plots and the disease severity in the various fungicide treatments detected in each instance was markedly and statically lower than in the controls (Table 2). The other treatments were similar (Table 2). The control efficiency in the conventional treatment $(79.3 \%)$ was statistically similar to that of the treatment with mancozeb $70.6 \%$. On the other hand, mancozeb alone showed control efficiency (72.6\%) lower than the mixture cymoxanil + maneb $(93.4 \%)$. The conventional method received seven sprayings, while in the other treatments, only six sprayings were used.

\section{Experiment 3: Season 2003/04}

The first leaf downy mildew symptoms were observed on October 10,2003 (25 days after bud burst). In this season, the treatment timing based on CDDSV of $12-14$ was assessed in the preceding season. Effectiveness of treatments timed according to the warning system was compared to that of the conventional spraying method and untreated controls. Eight sprayings were used in the conventional method and five were required when the warning system was used.

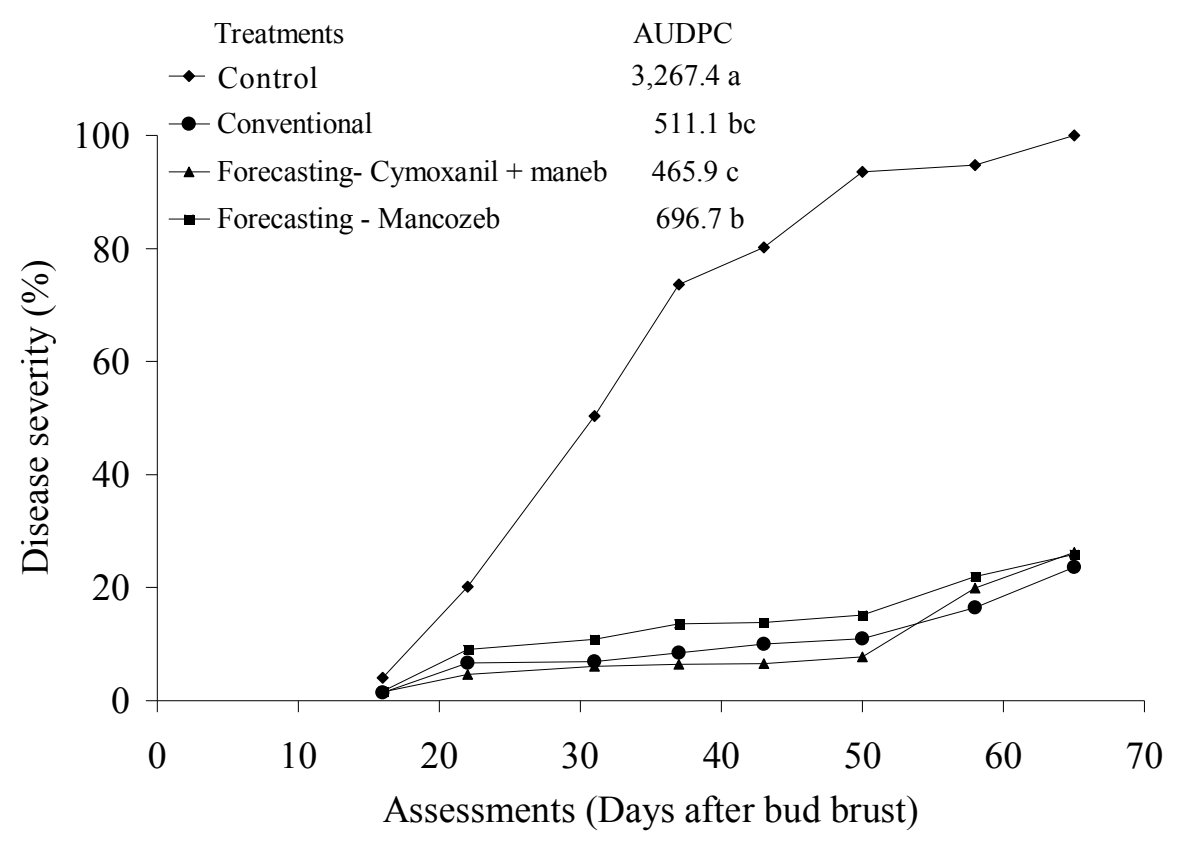

Figure 2. Disease progress curves and areas under the disease progress curves (AUDPC) for grape downy mildew considering leaf severity in the treatments, cultivar Isabel, 2002/03 growing season. Means followed by the same letter do not differ according to Tukey's $(\mathrm{P}<0.05)$ multiple range test.

Table 2. Comparison of the warning system with the conventional method on the downy mildew incidence and control in grape bunches. Cultivar Isabel, 2002/03 growing season in Experiment 2

\begin{tabular}{|c|c|c|c|c|c|c|}
\hline Treatments & Applications(NA) & \multicolumn{4}{|c|}{ Incidence (\%) } & Control (\%) \\
\hline Check NA $=0$ & 0 & 53.5 & 73.7 & 84.5 & 70,6 a & 0.0 \\
\hline Conventional system ( $6-8$ days $)$ & 7 & 5.2 & 19.5 & 19.5 & $14.7 \mathrm{~b}$ & 79.2 \\
\hline Mancozeb (CDDSV $12-14)$ & 6 & 18.2 & 21.2 & 22.5 & $20.7 \mathrm{~b}$ & 70.6 \\
\hline
\end{tabular}

Conventional system, application of mancozeb alternated with cymoxanil + maneb at $7-8$ days interval; application of mancozeb or cymoxanil + maneb according to CDDVS $=$ cumulative daily disease severity values. $\mathrm{NA}=$ number of fungicide applications in the treatment.

*Means followed by the same letter in the column do not differ according to Tukey's (5\%) multiple range test. 


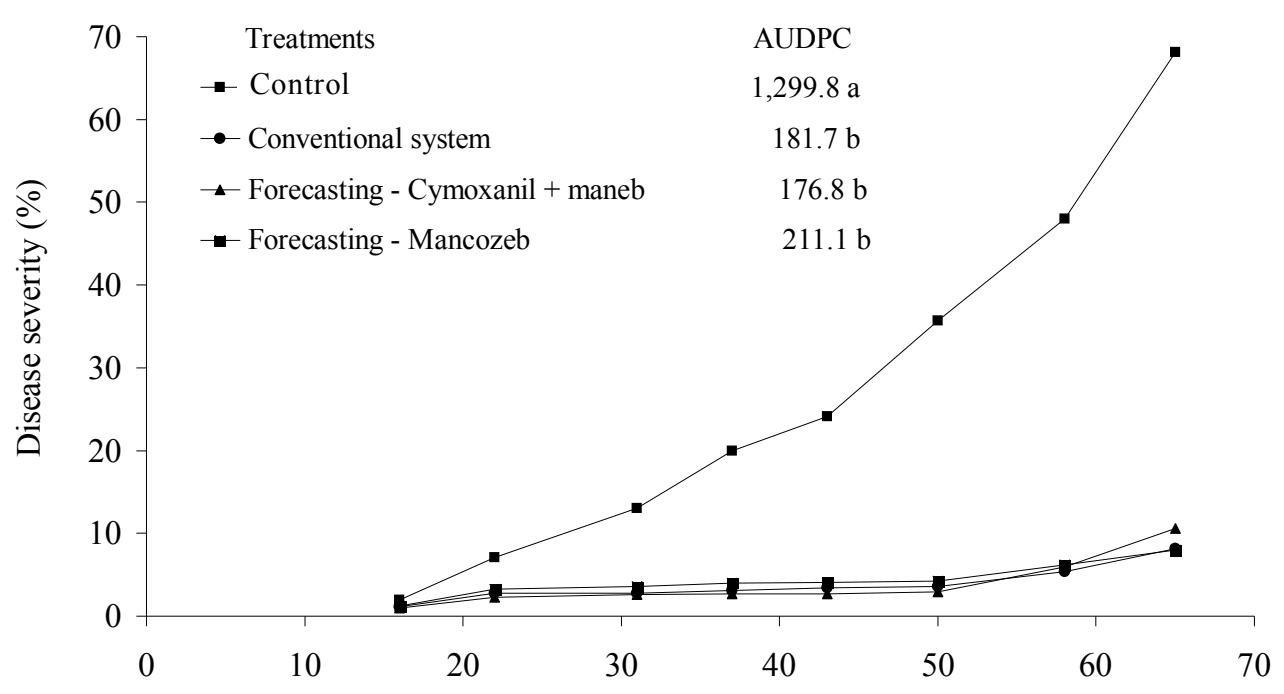

Assessments (Days after bud burst)

Figure 3. Disease progress curves and areas under the disease progress curves (AUDPC) for grape downy mildew considering leaf severity in the treatments, cultivar Isabel, 2003/04 growing season. Means followed by the same letter do not differ according to Tukey's $(\mathrm{P}<0.05)$ multiple range test.

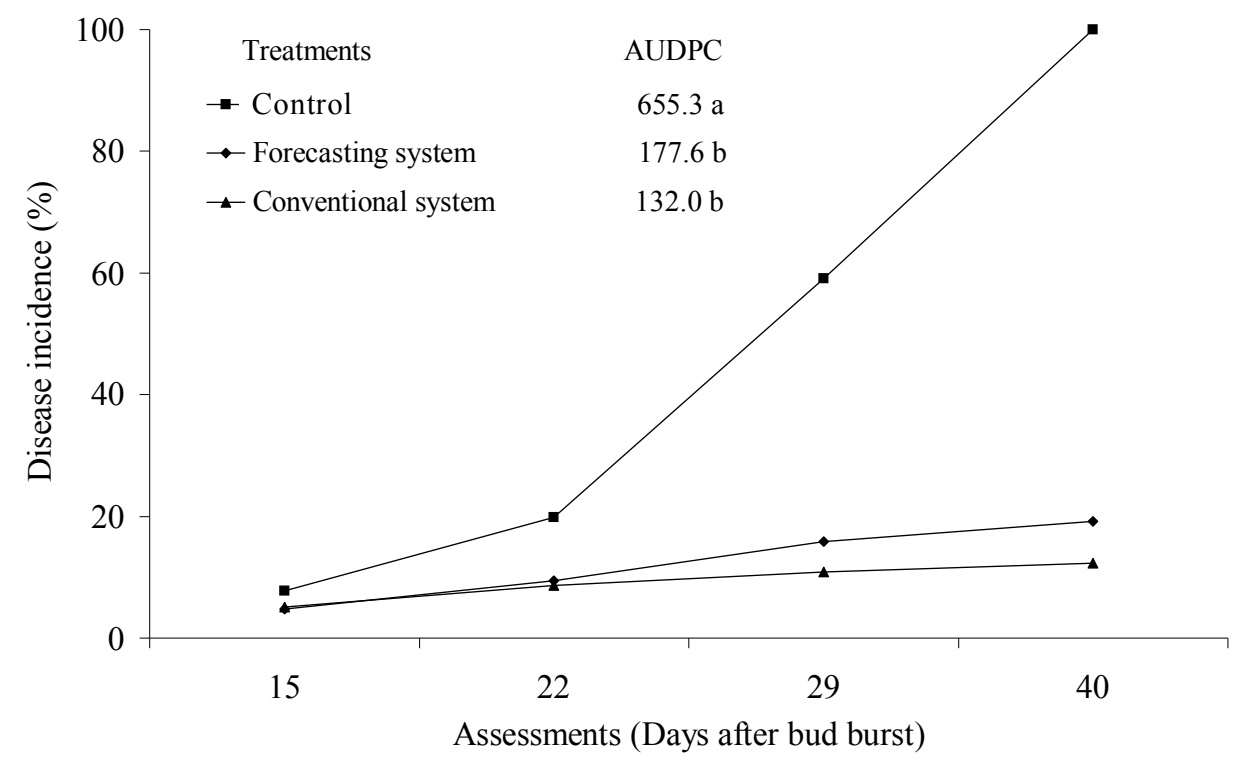

Figure 4. Disease progress curves and areas under the disease progress curves (AUDPC) for grape downy mildew considering leaf incidence in the treatments, cultivar Isabel, 2003/04 growing season. Means followed by the same letter do not differ according to Tukey's (P<0.05) multiple range test.

Severity of downy mildew on the foliage was statistically similar for the treatments: conventional and CDDVS of 12-14, independent of the used fungicide (Figures 3 and 4).

The use of micro-climate model resulted in good control of downy mildew while, in comparison to the conventional method, the required number of sprayings was reduced by $14.3 \%$ in the $2002 / 03$ growing season and by $3.5 \%$ in $2003 / 04$ season. We conclude that the warning system could contribute to the sustainability of the grape production in Rio Grande do Sul on account of the reduced cost and the protection for the environment by using less amount of chemicals.

The experimentally developed and validated model was investigated in a commercial grape orchard in Farroupilha - RS, based on the CDDSV of $12-14$ as a criterion to schedule the first and further fungicide applications. The grower's conventional method required vines to be sprayed 13 times, and according to the new model only eight applications result in similar disease control.

\section{REFERENCE GUIDELINES}

1. Abraham, V.; Kushalapa, A.C.; Carisse, O.; Bourgeois, G.; Auclair, P. Comparison of decision methods to initiate fungicide application against Cercospora blight of carrot. Phytoprotection, Québec, v.76, n.3, p. 91-99, 1995. 
2. Campbell, C. L. ; Madden, L. V. Introduction to plant disease epidemiology. New York, John Wiley, 1990. 532p.

3. Ellis, M.A.; Madden, L.V.; Wilson, L.L. Evaluation of an electronic apple scab predictor for scheduling fungicides with curative activity. Plant Disease, Saint Paul, v.68, n. p.1055-1057, 1984.

4. Freire, L.M.M.; Freire, J.M.; Caldart, V.Z. Transformação na estrutura produtiva dos viticultores da serra Gaúcha 1985 1991. Bento Gonçalves: EMBRAPA, CNPUV 1992. 44p. (EMB.CNPUV-Doc.7).

5. Hyre, R.A. Progress in forecasting late blight of potato and tomato. Plant Disease Reporter, Beltsville, v.38, n. p.245253,1954 .

6. Kuhn, G.B.; LovateL, J.L.; Prezotto, O.P; Rivaldo, O.F.; Mande1li, F.; Sônego, O.R. O cultivo da videira: informações básicas. 2.ed. Bento Gonçalves: Embrapa-CNPUV, 1996. 60p. (circular técnica, 10).

7. Lalancette, M. A.; Ellis, M. A.; Madden, L.V. Development of an infection efficiency model for Plasmopara viticola on American grape based on temperature and duration of leaf wetness. Phytopathology, Saint Paul, v. 78, n. p.794-800, 1988.

8. Madden, L.; PennypackeR, S. P.; Mcnab, A. A. Fast, a forecast system for Alternaria solani on tomato. Phytopathology, Saint Paul, v. 68, n. p.1354-1358, 1978.

9. Madden, L.V.; Ellis, M.A.; Lalancette, N.; Hughes, G.; Wilson, L.L. Evaluation of a disease warning system for downy mildew of grapes. Plant Disease, Saint Paul, v. 84, n. p.. 549-554, 2000

10. Mello, L. M. R. de. I - Cadastro vitícola. In.: MELLO, L.M.
R. de. I (Ed.). Cadastro vitícola do Rio Grande do Sul. 1995 a 2000. Versão 1.0. Bento Gonçalves: Embrapa Uva e Vinho; Ibravin, 2001. 1 CD-Rom.

11. Mendes, C. S. Flutuação anual do inóculo no ar, desenvolvimento e validação de um sistema de previsão do míldio da videira. 2002. 123p.Dissertação (Mestrado) Universidade de Passo Fundo.

12. Mendes, C. S.; Reis, E.M.; Sônego, O. R. Flutuação anual de esporangiosporos de Plasmopara viticola, no ar, em Bento Gonçalves, RS. Summa Phytopthologica, Botucatu, v.29, n.4, p.362-364, 2003.

13. Muckensturm, N.; Magnien, C.; Jacquin, D. MILVIT: un nouveau modèle de prévision des risques mildiou. Phytoma, Paris, v. 419, p. 34-36, 1990.

14. Orlandini, S.; Gozzini, B.; Rosa, M.; Egger, E.; Storchi, P.; Maracchi, G.; Miglietta, F. PLASMO: A simulation model for control of Plasmopara viticola on grapevine. Bulletin OEPP/EPPO, Hoboken, v. 23, p.619-626, 1993

15. Rosa, M.; Genesio, R.; Gozzini, B.; Maracchi, G.; Orlandini, S. PLASMO: a computer program for grapevine downy mildew development forecasting. Computers and Electronics in Agriculture, Amsterdan, v.9, p.205-215. 1993.

16. Sutton, J. C. Predictive value of weather variables in the epidemiology and management of foliar diseases. Fitopatologia Brasileira, Brasília, DF, v.13, n. p.305-312, 1988.

17. Wallin, J. R. Summary of recent progress in predicting late blight epidemics in United States and Canada. American Potato Journal, New York, v. 39, p. 306-312. 1962. 